\title{
Soybean hulls replacing ground corn in diets for early lactation Saanen goats: intake, digestibility, milk production and quality ${ }^{1}$
}

\section{Maximiliane Alavarse Zambom ${ }^{2}$, Claudete Regina Alcalde ${ }^{2}$, Daniele Cristina da Silva $\mathrm{Kazama}^{2}$, Elias Nunes Martins ${ }^{2}$, Juliano Hideo Hashimoto ${ }^{2}$, Makoto Matsushita ${ }^{3}$, Carlos Eduardo Crispim Oliveira Ramos ${ }^{2}$, Paula Adriana Grande ${ }^{2}$}

\footnotetext{
1 Project financed by Fundação Araucária.

2 Departamento de Zootecnia, Universidade Estadual de Maringá - UEM.

${ }^{3}$ Departamento de Química, Universidade Estadual de Maringá - UEM.
}

\begin{abstract}
The objective of this study was to evaluate productive performance and milk quality of Saanen goats fed diets with soybean hulls replacing ground corn (0,50 and 100\% replacement) in early lactation (from birth to 50 days of lactation). Fourteen goats $(72.30 \pm 9.14 \mathrm{~kg}$ of $\mathrm{BW})$ were used in a completely randomized design. Animals were confined in individual stalls, with daily control of feed intake and milk production. On the 30th day of lactation, fecal sampling started in order to determine nutrients digestibility. Every month, milk samples were collected for analyses of fat, protein, lactose and total solid percentage, somatic cell count, N-urea, acidity, density and also milk fatty acid profile. No differences were observed between diets for body weight, daily weight gain and intake ( $\mathrm{kg} / \mathrm{day})$ of dry matter, organic matter, crude protein or indigestible neutral detergent fiber. However, for neutral detergent fiber intake, the diet with complete substitution presented the best results. Cocerning digestibility coefficients of dry matter and nutrients (organic matter, crude protein and neutral detergent fiber) the diet with $100 \%$ replacement also presented the best results. For milk production, milk production efficiency and milk composition, no difference was observed between diets. For milk fatty acid profile, there were differences between diets for some fatty acids. Soybean hulls can be used replacing ground corn in diets for Saanen goats in the early lactation, because it improves the digestibility of the diet and nutrients, does not change productive performance or the milk physicalchemical quality and increases the content of $n-3$ fatty acids in milk.
\end{abstract}

Key Words: agro industry by-product, digestion, fatty acids, goat

\section{Introduction}

The goat milk production depends on milk aptitude of animals, the nutritive value of the feed, the dry matter intake level of the animal, and also management and environmental factors. However, to improve the milk production performance, it is necessary to utilize feeding strategies during the different animal physiologic stages.

The efficient utilization of feeds to animals depends to an adequate supply of energy. The causes of energy disability can be associated to low intake and/or feed quality, especially the high content of fiber or low content of dry matter in the feed.

The neutral detergent fiber (NDF) content in the diet is negatively correlated to the dry matter intake (DMI) because of the slower fermentation and more permanence time in the rumen. However, more digestible fiber can stimulate the intake by increasing the passage rate (Robinson \& McQueen, 1997).
The most dairy ruminants diets are based on cereals containing rapidly degradable starch. The fermentation of starch and soluble sugars can increase the lactate production, contributing to decrease in $\mathrm{pH}$ and fiber digestion in the rumen. The use of low starch and high hemicelluloses and pectin feeds regulates the lactic acid production, avoiding the $\mathrm{pH}$ and milk production drop, resulting in a bigger total production at lactation.

Soybean hulls can replace corn grain to supply about $30 \%$ of the dry matter (DM) in high-grain content diets without negatively affecting either the fermentation or digestion of nutrients in the gastrointestinal tract or the performance of dairy cows (Ipharraguerre \& Clark, 2003).

The corn replacement for early lactation cows, according Mansfiel \& Stern (1994) and Ipharraguerre et al. (2002), did not show differences for dry matter intake or digestibility of dry matter, crude protein and NDF, although the NDF intake was higher for the diets with soybean hulls.

Several studies (Coomer et al., 1993; Mansfiel \& Stern, 1994; Ipharraguerre et al., 2002) evaluated the use of 
soybean hulls in the diet of early lactation cows and did not verify differences $(\mathrm{P}>0.05)$ with the control diet for milk production. Nevertheless, the authors verified a positive linear effect for milk fat percentage in function of soybean hulls inclusion in the diet. Therefore, the objective of this study was to evaluate the voluntary intake and digestibility and milk production, quality and fatty acid profile in Saanen goats at early lactation fed diets with soybean hulls replacing ground corn.

\section{Material and Methods}

The experiment was conducted in the Iguatemi Experimental Farm Caprile and in the Laboratory of feed analysis and animal nutrition from Universidade Estadual de Maringá from August to September, 2004.

Fourteen multiparous Saanen goats $(72.3 \pm 9.2 \mathrm{~kg}$ of body weight - BW), during the early lactation (50 days from birth) were used. The criteria for animal allocation in the diets were: milk production level, body weight, age and order of birth. Goats were kept in individual stalls with drinker and feeder. Diets were supplied twice a day, at $10 \mathrm{~h} 00$ and $16 \mathrm{~h} 00$, since prepartum. The milking was done at $7 \mathrm{~h} 30$ and $15 \mathrm{~h} 00$ and, immediately after, the animals were conducted to a solarium for two hours.
The diets were based on corn silage, soybean meal, and soybean hulls and ground corn (Tables 1 and 2) and presented different levels of soybean hulls replacing ground corn: 0,50 and $100 \%$ substitution. The balancing of diets was done based on energy and metabolized protein requirements from the AFRC (1993) and mineral requirements from the NRC (1981) for Saanen goats with $60 \mathrm{~kg}$ of body weight and $3.0 \mathrm{~kg}$ of milk production a day (Table 3).

Feed intake (corn silage and concentrate) was recorded daily. At every 15 days, samples of diets and orts were collected, homogenized and composed. After, samples were ground to pass through a $1 \mathrm{~mm}$ screen sieve and stored.

For digestibility evaluation, in early lactation phase (30 days from birth), samples of feces were collected for six consecutive days at $8 \mathrm{~h} 00,10 \mathrm{~h} 00,12 \mathrm{~h} 00,14 \mathrm{~h} 00,16 \mathrm{~h} 00$, and $18 \mathrm{~h} 00$, respectively for each day. Indigestible NDF was used as an internal marker to estimate the fecal output (Cochran et al., 1986). The indigestible NDF was estimated by incubation of F57 filter bags Ankom ${ }^{\circledR}$ in the rumen for $144 \mathrm{~h}$ with samples of feeds, orts and feces followed by NDF analysis, according to Detmann et al. (2001).

The diets supplied, refused and feces were analysed for dry matter (DM), ash, crude protein (CP), ether extract (EE), lignin, calcium and phosphorus according to

Table 1 - Chemical composition of the feeds

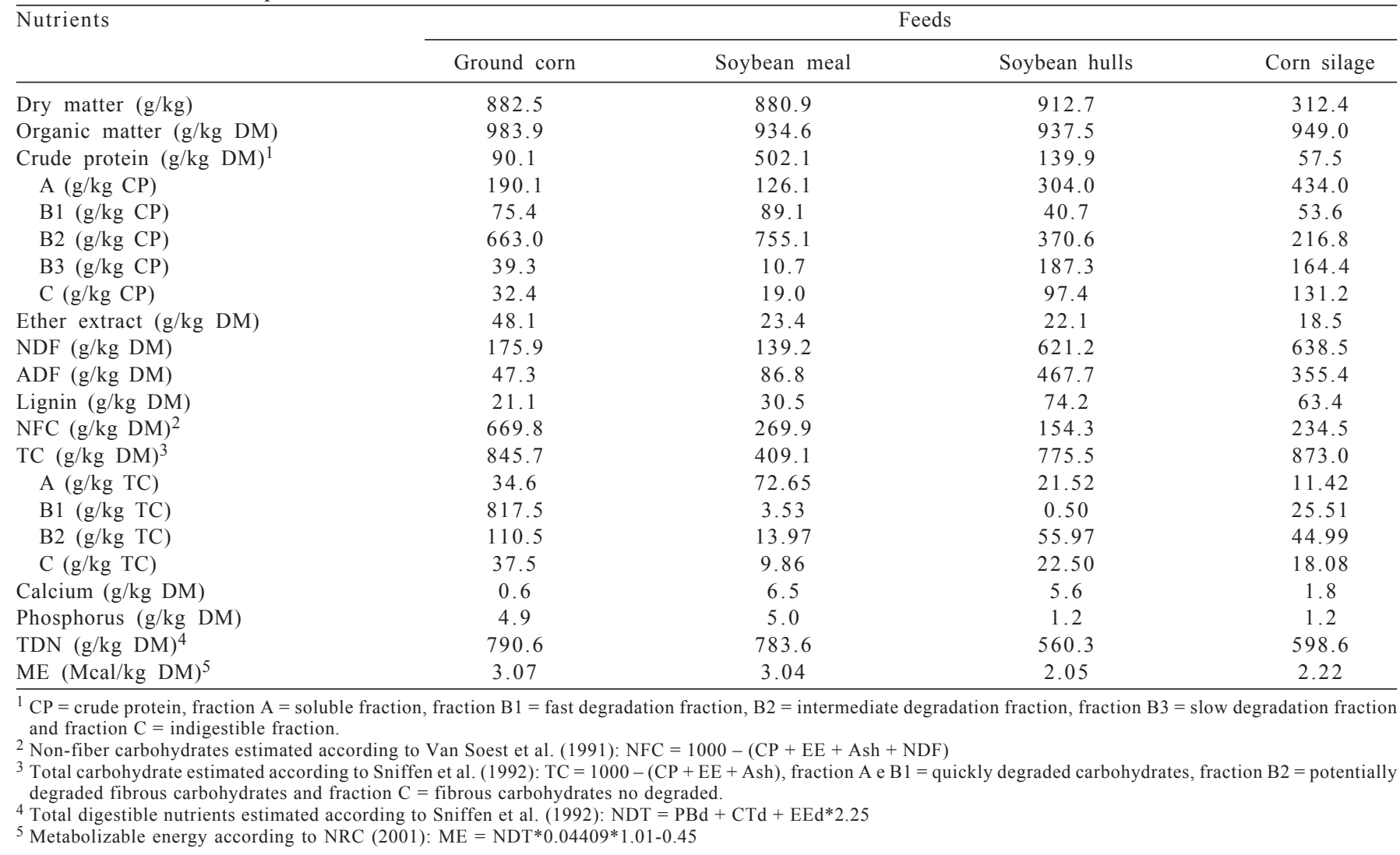


Table 2 - Composition of main fatty acids of the feeds $(\mathrm{g} / 100 \mathrm{~g})$

\begin{tabular}{|c|c|c|c|c|}
\hline \multirow[t]{2}{*}{ Fatty acids $(\mathrm{g} / 100 \mathrm{~g})$} & \multicolumn{4}{|c|}{ Feeds } \\
\hline & Ground corn & Soybean meal & Soybean hulls & Corn silage \\
\hline $14: 0$ & 0.19 & 0.17 & 0.40 & 0.23 \\
\hline $18: 0$ & 2.17 & 3.76 & 7.39 & 3.38 \\
\hline $18: 1 \mathrm{n}-9$ & 32.46 & 16.61 & 16.11 & 30.03 \\
\hline $18: 1 \mathrm{n}-7$ & 1.28 & 2.01 & 3.99 & - \\
\hline $18: 2 n-6$ & 46.57 & 53.60 & 32.83 & 38.31 \\
\hline $18: 3 n-3$ & 0.74 & 4.03 & 4.10 & 5.28 \\
\hline $20: 3 n-9$ & 0.39 & 0.34 & 1.29 & 0.30 \\
\hline $20: 4 n-3$ & 1.19 & 0.15 & 0.55 & 0.78 \\
\hline $20: 5 n-3$ & 0.17 & 0.25 & 10.08 & 0.85 \\
\hline $22: 5 n-3$ & 0.25 & 0.84 & 1.06 & 1.43 \\
\hline $22: 6 n-3$ & 0.37 & 0.27 & 1.93 & 0.52 \\
\hline
\end{tabular}

Silva \& Queiroz (2004), and NDF and ADF, according Van Soest et al. (1991). Starch was determined by the enzymatic method proposed by Poore et al.(1989), adapted by Pereira \& Rossi (1995). The total carbohydrates were estimated by Sniffen etal. (1992).

Table 3 - Ingredient and chemical composition of experimental diets

\begin{tabular}{|c|c|c|c|}
\hline \multirow[t]{2}{*}{ Feeds } & \multicolumn{3}{|c|}{ Diets $^{1}$} \\
\hline & 0SBH & $50 \mathrm{SBH}$ & $100 \mathrm{SBH}$ \\
\hline Corn silage $(\mathrm{g} / \mathrm{kg}$ of $\mathrm{DM})$ & 400.0 & 400.0 & 400.0 \\
\hline Soybean meal $(\mathrm{g} / \mathrm{kg}$ of $\mathrm{DM})$ & 172.9 & 182.7 & 167.8 \\
\hline Ground corn $(\mathrm{g} / \mathrm{kg}$ of $\mathrm{DM})$ & 401.9 & 201.8 & - \\
\hline Soybean hulls $(\mathrm{g} / \mathrm{kg}$ of $\mathrm{DM})$ & - & 194.6 & 413.2 \\
\hline Salt $(\mathrm{g} / \mathrm{kg}$ of $\mathrm{DM})$ & 12.1 & 12.1 & 12.2 \\
\hline Limestone $(\mathrm{g} / \mathrm{kg}$ of $\mathrm{DM})$ & 6.3 & 2.5 & - \\
\hline Dicalcium phosphate $(\mathrm{g} / \mathrm{kg}$ of $\mathrm{DM})$ & 1.9 & 1.4 & 1.6 \\
\hline Mineral supplement $(\mathrm{g} / \mathrm{kg} \text { of } \mathrm{DM})^{2}$ & 5.0 & 5.0 & 5.0 \\
\hline Dry matter $(\mathrm{g} / \mathrm{kg})$ & 657.3 & 662.6 & 668.8 \\
\hline Organic matter (g/kg of DM) & 938.7 & 934.1 & 927.5 \\
\hline Crude protein $(\mathrm{g} / \mathrm{kg}$ of $\mathrm{DM})$ & 131.5 & 144.7 & 150.0 \\
\hline Ether extract $(\mathrm{g} / \mathrm{kg}$ of $\mathrm{DM})$ & 28.0 & 23.7 & 19.2 \\
\hline $\operatorname{Starch}(g / k g$ of $\mathrm{DM})$ & 356.1 & 228.7 & 100.0 \\
\hline $\mathrm{NDF}(\mathrm{g} / \mathrm{kg}$ of $\mathrm{DM})$ & 354.7 & 435.2 & 525.9 \\
\hline $\mathrm{ADF}(\mathrm{g} / \mathrm{kg}$ of $\mathrm{DM})$ & 172.2 & 247.6 & 331.4 \\
\hline Lignin $(\mathrm{g} / \mathrm{kg}$ of $\mathrm{DM})$ & 37.5 & 47.2 & 57.9 \\
\hline $\mathrm{TC}(\mathrm{g} / \mathrm{kg} \text { of } \mathrm{DM})^{3}$ & 778.7 & 765.3 & 757.9 \\
\hline $\mathrm{NFC}(\mathrm{g} / \mathrm{kg} \text { of } \mathrm{DM})^{4}$ & 424.0 & 330.1 & 231.9 \\
\hline Calcium $(\mathrm{g} / \mathrm{kg}$ of $\mathrm{DM})$ & 4.1 & 3.6 & 3.8 \\
\hline Phosphorus (g/kg of DM) & 2.6 & 2.4 & 2.3 \\
\hline TDN $(\mathrm{g} / \mathrm{kg} \text { of } \mathrm{DM})^{5}$ & 639.2 & 605.9 & 566.6 \\
\hline $\mathrm{ME}(\mathrm{Mcal} / \mathrm{kg} \text { of } \mathrm{DM})^{6}$ & 2.40 & 2.25 & 2.07 \\
\hline
\end{tabular}

${ }^{1} 0 \mathrm{SBH}-0 \mathrm{~g} / \mathrm{kg}$ of soybean hulls as a ground corn replacement, $50 \mathrm{SBH}-500 \mathrm{~g} / \mathrm{kg}$ of soybean hulls as a ground corn replacement, $100 \mathrm{SBH}-1000 \mathrm{~g} / \mathrm{kg}$ of soybean hulls as a ground corn replacement.

${ }^{2}$ Chemical composition (by kg of product): $80.00 \mathrm{~g} \mathrm{Ca}, 65.00 \mathrm{~g} \mathrm{P}, 126.00 \mathrm{mg} \mathrm{Co}$, $21.00 \mathrm{mg} \mathrm{Mg}, 4400.00 \mathrm{mg} \mathrm{Mn}, 185.00 \mathrm{mg} \mathrm{Na}, 4680.00 \mathrm{mg} \mathrm{Zn}, 45.00 \mathrm{mg} \mathrm{Se}$, $60.00 \mathrm{mg} \mathrm{I}, 23.00 \mathrm{~g} \mathrm{~S}, 615.79 \mathrm{mg} \mathrm{F}$ (max.), $7000.00 \mathrm{mg}$ Niacin (commercial product).

3 Total carbohydrates estimated according to Sniffen et al. (1992): TC $=1000-$ $(\mathrm{CP}+\mathrm{EE}+\mathrm{Ash})$.

${ }^{4}$ Non-fiber carbohydrates estimated according to Van Soest et al. (1991): NFC $=$ $1000-(\mathrm{CP}+\mathrm{EE}+\mathrm{Ash}+\mathrm{NDF})$.

5 Total digestible nutrients estimated according to Sniffen et al. (1992): TDN = $\mathrm{PBd}+\mathrm{CTd}+\mathrm{EEd} * 2.25$.

${ }^{6}$ Metabolizable energy according to NRC (2001): $\mathrm{ME}=\mathrm{NDT} * 0.04409 * 1.01-0.45$.
Animals were weighed weekly, immediately after the milking and before morning feeding. On the 30 th day from birth, blood samples were taken four hours after morning feeding from the jugular vein into $10 \mathrm{~mL}$ glass tubes. The plasma was obtained by centrifugation $(3,500 \mathrm{rpm}$ for 15 $\mathrm{min}$ ) and analysed for $\mathrm{N}$-urea concentration by a colorimetric method.

During the evaluated lactation period, the milk production was recorded daily. Milk samples were collected monthly for physical-chemical analysis at $7 \mathrm{~h} 30$ and $15 \mathrm{~h} 00$.

The milk acidity was measured by the Dornic method and density by Quevene thermolactodensimeter and the values were corrected for $15^{\circ} \mathrm{C}$ through the table presented by Tronco (1997).

Milk samples were kept at room temperature by using 2-brome-2-nitropropane-1,3diol (Bronopol ${ }^{\circledR}$ ), for determination of protein, fat, lactose and total solid concentrations by infrared spectroscopy (Bentley $2000^{\circledR}$ ) in the Laboratory of Programa de Análise de Rebanhos Leiteiros do Paraná(PARLPR) from Associação Paranaense de Bovinos da Raça Holandesa. The milk somatic cell count (SCC) was obtained using an electronic counter (Somacount $500^{\circledR}$ ) and both, Bentley and Somacount were calibrated for cow milk. The 3.5\% fat-corrected milk (FCM) was calculated according the equation of Gravert (1987):

$$
3.5 \% \mathrm{FCM}=0.4337 \mathrm{MP}+16.218 \mathrm{FP}
$$

where: MP: milk production $(\mathrm{kg} / \mathrm{d}) ; \mathrm{FP}$ : fat production $(\mathrm{kg} / \mathrm{d})$.

For the determination of $\mathrm{N}$-urea and fatty acids in the milk, the sample was collected 15 days from birth using (Bronopol ${ }^{\circledR}$ ) and kept frozen. The milk fat was extracted by centrifugation $\left(8^{\circ} \mathrm{C}, 3,000 \mathrm{rpm}\right.$ for $\left.30 \mathrm{~min}\right)$ and the milk serum was used for $\mathrm{N}$-urea concentration analysis as described for blood.

Milk fat was methylated according to the method 5509 of ISO (1978) using KOH/methanol. Fatty acid methyl ester 
profiles were measured by GLC on a 14-A Shimadzu ${ }^{\circledR}$ chromatograph equipped with a flame ionization detector and a CP-Sil 88 (Chrompack) fused silica capillary column ( $100 \mathrm{~m}$ and $0.25 \mathrm{~mm}$ i.d., $0.25 \mu \mathrm{m}$ film thickness). To register the fatty acid concentrations, the GLC was coupled to a Processor-Integrator CG-300 ${ }^{\circledR}$ (Instrumentos Científicos $\left.\mathrm{CG}^{\circledR}\right)$. The column parameters were as follows: initial column temperature of $60^{\circ} \mathrm{C}$ was maintained for $4 \mathrm{~min}$; the temperature was then programmed at $40{ }^{\circ} \mathrm{C}$ per minute to $140{ }^{\circ} \mathrm{C}$. This temperature was maintained for $10 \mathrm{~min}$, and then increased $5^{\circ} \mathrm{C}$ per minute to $225^{\circ} \mathrm{C}$, and remained at this temperature for $12 \mathrm{~min}$. Injector and detector temperatures were $220^{\circ} \mathrm{C}$ and $240{ }^{\circ} \mathrm{C}$, respectively. The carrier gas was hydrogen at $1.2 \mathrm{~mL} / \mathrm{min}$. Hydrogen flow to the detector was $30 \mathrm{~mL} / \mathrm{min}$, airflow was $300 \mathrm{~mL} / \mathrm{min}$, and the flow of $\mathrm{N}_{2}$ make-up gas was $30 \mathrm{~mL} / \mathrm{min}$. The volume injected was $1 \mu \mathrm{L}$ of sample in duplicate. Fatty acid peaks were identified using pure methyl ester standards (Sigma, E6885).

The experimental design was completely randomized with the following repetitions by treatment: $\mathrm{n}=3$ for $0 \%$, $\mathrm{n}=5$ for $50 \%$ and $\mathrm{n}=6$ for $100 \%$ substitution. The number of repetitions in the treatments was different because some animals died after birth.

Data were analysed by variance analysis and polynomial regression analysis considering the levels of soybean hulls replacing ground corn at 0.05 of probability.

\section{Results and Discussion}

Initial (ILW, $\mathrm{kg}$ ) and final (FLW, kg) live weight, average daily gain (ADG, $\mathrm{kg} / \mathrm{d}$ ), dry matter (DMI kg/d), crude protein (CPI) and indigestible neutral detergent fiber (iNDF) intake were not different $(\mathrm{P}>0.05)$ for treatments (Table 4$)$.

However, dry matter intake $(\mathrm{g} / \mathrm{kg} \mathrm{LW})$ showed quadratic effect $\left(\mathrm{Y}=3.039+0.0037 \mathrm{X}+0.00019 \mathrm{X}^{2}\right)$, but neutral detergent fiber intake (NDFI kg/d) and organic matter (OMD), neutral detergent fiber (NDFD) digestibility, and total digestible nutrients had positive linear effect $(\mathrm{P}<0.05)$, with soybean hulls replacing ground corn at $100 \%$ in the diet. The results showed that even though soybean hulls are an alternative feed, classified as dry roughage (NRC, 2001) and presenting high NDF content, they provided better digestibility of dry matter and nutrients (Table 4).

The intake of a diet with $148 \mathrm{~g} / \mathrm{kg}$ of CP and $330 \mathrm{~g} / \mathrm{kg}$ of NDF by Saanen goats $(52 \mathrm{~kg})$ in early lactation ( $46 \mathrm{~d}$ from birth) resulted in DMI of $2.62 \mathrm{~kg} /$ day, DMD of $0.72(\mathrm{~kg} / \mathrm{kg})$, CPD of $0.74(\mathrm{~kg} / \mathrm{kg}$ ) and NDFD of $0.51(\mathrm{~kg} / \mathrm{kg}$ ) (Baya etal., 2001). In this experiment the NDFD in the diet with replacement at $50 \%$ was $0.50(\mathrm{~kg} / \mathrm{kg})$ and the DMI was $2.36 \mathrm{~kg} /$ day, with positive linear effect $(\mathrm{Y}=0.473+0.00215 \mathrm{X})$ (Table 4$)$.

The NDF content in the diet is negatively correlated with DMI due the slower fermentation and bigger residence time in the rumen. However, the more digestible fiber can

Table 4 - Live weight, intake and digestibility of dry matter and nutrients of diets for Saanen goats fed soybean hulls replacing ground corn

\begin{tabular}{|c|c|c|c|c|c|c|c|}
\hline \multirow[t]{3}{*}{ Variables $^{2}$} & \multicolumn{5}{|c|}{ Diets $^{1}$} & \multirow[t]{3}{*}{$\mathrm{R}^{2}$} & \multirow[t]{3}{*}{$\mathrm{CV}$} \\
\hline & \multirow{2}{*}{$\begin{array}{l}0 \mathrm{SBH} \\
(\mathrm{n}=3)\end{array}$} & \multirow{2}{*}{$\begin{array}{l}50 \mathrm{SBH} \\
(\mathrm{n}=5)\end{array}$} & \multirow{2}{*}{$\begin{array}{c}100 \mathrm{SBH} \\
(\mathrm{n}=6)\end{array}$} & \multicolumn{2}{|c|}{$P$ value ${ }^{3}$} & & \\
\hline & & & & $\mathrm{L}$ & Q & & \\
\hline ILW (kg) & 69.37 & 77.26 & 67.35 & 0.538 & 0.138 & - & 13.7 \\
\hline FLW (kg) & 70.53 & 79.48 & 70.62 & 0.725 & 0.104 & - & 11.9 \\
\hline ADG (kg/day) & 0.02 & 0.04 & 0.06 & 0.462 & 1.000 & - & 155.9 \\
\hline DMI (g/kg LW) & 33.30 & 30.40 & 37.00 & 0.087 & 0.052 & 1.00 & 11.3 \\
\hline DMI (kg/day) & 2.34 & 2.36 & 2.53 & 0.396 & 0.715 & - & 13.9 \\
\hline OMI (kg/day) & 2.19 & 2.20 & 2.34 & 0.465 & 0.725 & - & 13.9 \\
\hline CPI (kg/day) & 0.31 & 0.34 & 0.38 & 0.046 & 0.866 & 1.00 & 13.6 \\
\hline EEI (kg/day) & 0.06 & 0.07 & 0.06 & 0.061 & 0.579 & - & 20.7 \\
\hline NFDI (kg/day) & 0.77 & 0.97 & 1.28 & 0.000 & 0.505 & 0.98 & 14.2 \\
\hline NFDI (g/kg LW) & 11.00 & 12.40 & 18.70 & 0.000 & 0.018 & 0.89 & 10.3 \\
\hline iNFDI (kg/day) & 0.36 & 0.40 & 0.48 & 0.020 & 0.529 & 0.95 & 15.4 \\
\hline TDNI (kg/day) & 1.27 & 1.40 & 1.58 & 0.064 & 0.882 & - & 15.2 \\
\hline DMD (kg/kg) & 0.54 & 0.60 & 0.63 & 0.023 & 0.733 & 0.98 & 8.4 \\
\hline OMD (kg/kg) & 0.56 & 0.62 & 0.67 & 0.011 & 0.765 & 0.99 & 8.0 \\
\hline CPD (kg/kg) & 0.52 & 0.56 & 0.60 & 0.063 & 0.063 & - & 10.4 \\
\hline EED $(\mathrm{kg} / \mathrm{kg})$ & 0.71 & 0.70 & 0.79 & 0.002 & 0.017 & 0.67 & 4.6 \\
\hline NDFD (kg/kg) & 0.35 & 0.50 & 0.57 & 0.000 & 0.145 & 0.96 & 7.8 \\
\hline NCFD (kg/kg) & 0.73 & 0.65 & 0.71 & 0.845 & 0.082 & - & 9.7 \\
\hline TDN (kg/kg) & 0.54 & 0.59 & 0.62 & 0.046 & 0.681 & 0.97 & 7.8 \\
\hline
\end{tabular}

${ }^{1} 0 \mathrm{SBH}-0 \mathrm{~g} / \mathrm{kg}$ of soybean hulls as a ground corn replacement, $50 \mathrm{SBH}-500 \mathrm{~g} / \mathrm{kg}$ of soybean hulls as a ground corn replacement, $100 \mathrm{SBH}-1000 \mathrm{~g} / \mathrm{kg}$ of soybean hulls as a ground corn replacement.

${ }^{2}$ ILW: initial live weight, FLW: final live weigh, DMG: daily main gain, DMI: dry matter intake, OMI: organic matter intake, CPI: crude protein intake, NDFI: neutra detergent fiber intake, iNDFI: indigestible neutral detergent fiber intake, DMD: dry matter digestibility, OMD: organic matter digestibility, CPD: crude protein digestibility, NDFD: neutral detergent fiber digestibility

${ }^{3} \mathrm{P}$ value: Probability of $0.05 ; \mathrm{L}=$ linear, $\mathrm{Q}=$ quadratic $\mathrm{NS}$ : $\mathrm{P}>0.05 ; \mathrm{R}^{2}$ : regression coefficient 
stimulate the intake by increasing the flow rate (Robinson \& McQueen, 1997), confirmed by the higher DMI ( $\mathrm{g} / \mathrm{kg}$ of LW) for the diet with complete replacement (Table 4).

The early lactation is a period in which the goats have the highest nutrient requirements, because in this period there is an increase in milk production, but the animals cannot consume the maximum of nutrients. Thus, to maximize the intake by feeds with high digestibility, it is important to improve the productive performance and to prevent problems of metabolic disorders.

The lactation phase affects the ruminal retention time; animals in early lactation can have a medium retention time for NDF of $30 \mathrm{~h}$, while in late lactation, approximately $45 \mathrm{~h}$ (Varga et al., 1998). Thus, lower retention time provides a higher flow rate, which can provide higher DMI. In this way, the differences by the effect of fiber digestibility on the intake can be related with the phase of lactation.

The feed intake capacity can be changed by the phase of lactation according Zambom et al. (2005a), who evaluated the dry matter intake and digestibility of diets with different roughage:concentrate ratio for Saanen goats in the early lactation and after lactation peak and observed differences for intake and digestibility of dry matter in early lactation.

The use of feed with different compositions for carbohydrate profile in diets for Alpine goats with 60 days from birth such as the utilization of disintegrated corn with straw and cobs in replacement to citric pulp provide a dry matter intake of $2.04 \mathrm{~kg} /$ day or $41.4 \mathrm{~g} / \mathrm{kg}$ of live weight and NDF intake of $0.61 \mathrm{~kg} /$ day or $12.3 \mathrm{~g} / \mathrm{kg}$ of live weight and also a negative linear effect for dry matter and NDF digestibility in function of inclusionof disintegrated corn with straw and cobs in the diet (Bomfim, 2003). This data also testifies the differences for the digestive process function of the type of carbohydrate utilized in the diets.

The soybean hulls replacing ground corn for early lactation Holstein cows, according Mansfield \& Stern (1994) and Ipharraguerre et al. (2002), did not alter the intake of dry matter and crude protein as the digestibility of organic matter, crude protein and NDF, even with a higher intake of NDF for diets with soybean hulls. However, Sarwar et al. (1992) utilized the same feed replacement for early lactation cows and observed higher NDF digestibility for diets with soybean hulls.

Milk production ( $\mathrm{kg} /$ day) and 3.5\% fat corrected milk production, milk efficiency production and milk quality (fat, protein, lactose and total solids percentages, milk urea nitrogen concentration, milk acidity, density and somatic cell count) were not affected by diets (Table 5).

The milk quality of goats can vary in function of several factors, such as type and quality of animal diets, breed, lactation period and climate, also the combined action of these factors in the environmental conditions of each country or region (Queiroga \& Costa, 2004).

It is important to know the mean values of milk quality of goats to have a standard comparison. Prata et al. (1998) evaluated 179 samples of milk of Saanen goats and obtained the following results: $37.4 \mathrm{~g} / \mathrm{kg}$ of fat, $32.7 \mathrm{~g} / \mathrm{kg}$ of protein, $43.5 \mathrm{~g} / \mathrm{kg}$ of lactose, $115.1 \mathrm{~g} / \mathrm{kg}$ of total solids, $1.0324 \mathrm{~g} / \mathrm{cm}^{3}$ of milk density and $16.11^{\circ} \mathrm{D}$ of milk acidity. The somatic cell count for goat milk must be lower than 1 million cells $/ \mathrm{mL}$ (Haenlein, 2001).

The soybean hulls replacing ground corn for Saanen goats of early lactation did not modify the milk production $(3.64 \mathrm{~kg} /$ day) and provided positive linear effect to milk fat $(\mathrm{Y}=3.467+0.0069 \mathrm{X})$, as observed by some studies utilizing

Table 5 - Production and composition of milk from Saanen goats fed soybean hulls replacing ground corn

\begin{tabular}{|c|c|c|c|c|c|c|c|}
\hline \multirow{3}{*}{ Variables $^{2}$} & \multicolumn{5}{|c|}{ Diets $^{1}$} & \multirow[t]{3}{*}{$\mathrm{R}^{2}(\%)$} & \multirow[t]{3}{*}{ CV (\%) } \\
\hline & \multirow{2}{*}{$\begin{array}{l}0 \mathrm{SBH} \\
(\mathrm{n}=3)\end{array}$} & \multirow{2}{*}{$\begin{array}{l}50 \mathrm{SBH} \\
(\mathrm{n}=5)\end{array}$} & \multirow{2}{*}{$\begin{array}{c}100 \mathrm{SBH} \\
(\mathrm{n}=6)\end{array}$} & \multicolumn{2}{|c|}{$\mathrm{P}$ value $^{3}$} & & \\
\hline & & & & $\mathrm{L}$ & Q & & \\
\hline MP (kg/day) & 3.73 & 3.62 & 3.57 & 0.866 & 0.965 & - & 34.2 \\
\hline MP $3.5 \%$ (kg/day) & 3.55 & 3.55 & 3.48 & 0.730 & 0.792 & - & 33.6 \\
\hline MPE & 1.59 & 1.52 & 1.39 & 0.444 & 0.890 & - & 24.7 \\
\hline Fat $(g / k g)$ & 32.4 & 32.9 & 38.7 & 0.057 & 0.343 & 0.82 & 13.4 \\
\hline Total solids $(\mathrm{g} / \mathrm{kg})$ & 119.1 & 113.7 & 121.1 & 0.452 & 0.120 & - & 5.7 \\
\hline MUN (mg/dL) & 16.69 & 13.17 & 17.63 & 0.337 & 0.031 & 1.00 & 17.8 \\
\hline Acidity $\left({ }^{\circ} \mathrm{D}\right)$ & 15.32 & 14.49 & 12.40 & 0.034 & 0.562 & 0.94 & 13.3 \\
\hline $\mathrm{D}(\mathrm{mg} / 1.000 \mathrm{~mL})$ & 1.028 & 1.027 & 1.027 & 0.073 & 0.410 & - & 0.0 \\
\hline $\operatorname{SCC}(\mathrm{cel} / \mathrm{mLx} 1000)$ & 337.67 & 1556.70 & 727.00 & 0.847 & 0.077 & - & 98.1 \\
\hline
\end{tabular}


cows in early lactation demonstrating a variation in milk quality (Coomer et al., 1993; Mansfield \& Stern, 1994; Ipharraguerre et al., 2002).

The milk fat content is the most variable nutrient because of the differences between breed, climate, feeding or their interaction (Queiroga \& Costa, 2004). Bomfim (2003) utilized disintegrated corn with straw and cobs replacing citrus pulp and observed $26.5 \mathrm{~g} / \mathrm{kg}$ of fat and $42.6 \mathrm{~g} / \mathrm{kg}$ of lactose in milk. Bava et al. (2001) evaluated a diet with $148 \mathrm{~g} / \mathrm{kg}$ of CP and $330 \mathrm{~g} / \mathrm{kg}$ of NDF and, observed a milk production of $4.37 \mathrm{~kg} / \mathrm{day}$, $36.7 \mathrm{~g} / \mathrm{kg}$ of milk fat, $30.5 \mathrm{~g} / \mathrm{kg}$ of protein, $49.8 \mathrm{~g} / \mathrm{kg}$ of lactose and $15.30 \mathrm{mg} / \mathrm{dL}$ of milk urea nitrogen. Goetsch et al. (2001) supplying a diet with $167 \mathrm{~g} / \mathrm{kg}$ of CP, $476 \mathrm{~g} / \mathrm{kg}$ of NDF and $2.42 \mathrm{Mcal}$ of metabolizable energy $/ \mathrm{kg}$ of DM, obtained a milk production of $3.77 \mathrm{~kg} /$ day with $37 \mathrm{~g} / \mathrm{kg}$ of milk fat, $30.6 \mathrm{~g} / \mathrm{kg}$ of protein and $41.3 \mathrm{~g} / \mathrm{kg}$ of lactose content. Zambom et al. (2005b) used different roughage:concentrate ratio in the diet and observed $32.3 \mathrm{~g} / \mathrm{kg}$ of fat, $27.4 \mathrm{~g} / \mathrm{kg}$ of protein, $45.1 \mathrm{~g} / \mathrm{kg}$ of lactose and 114.1 of total solids content in milk.

The milk urea nitrogen was higher $(\mathrm{P}<0.05)$ for the diet with $1000 \mathrm{~g} / \mathrm{kg}$ of soybean hulls $(27.03 \mathrm{mg} / \mathrm{dL})$ compared with the diet of $0 \%$ of soybean hulls $(14.07 \mathrm{mg} / \mathrm{dL})$ and
$500 \mathrm{~g} / \mathrm{kg}$ of soybean hulls $(16.26 \mathrm{mg} / \mathrm{dL})$, so quadratic effect was verified $\left(Y=13.172+0.0094 \mathrm{X}+0.0016 \mathrm{X}^{2}\right)$. This probably occurs because of the higher content of $\mathrm{CP}$ in the diet of $1000 \mathrm{~g} / \mathrm{kg}$ soybean hulls, which can provide more ammonia nitrogen in the rumen. The ammonia produced during the nitrogen metabolism in the rumen not utilized by microorganisms is absorbed by the ruminal wall, which provided a higher level of urea in the plasma with the addition of soybean hulls in the $\operatorname{diet}(\mathrm{Y}=19.117+0.1406 \mathrm{X})$. Ammonia is a toxic molecule, so, through the blood, it is transported into the liver and becomes urea (Russel et al., 1992), which is a small molecule that easily spreads through the body tissues (Mouro et al., 2002).

The replacement of corn by soybean hulls in diets of early-lactation cows did not alter the milk production (Coomer et al., 1993; Mansfiel \& Stern, 1994; Ipharraguerre et al., 2002), but for milk fat, positive linear effect in function of soybean hulls inclusion in the diet was observed. In the same way, Zenou \& Miron (2005) fed soybean hulls in replacement of grains with high starch content for lactating sheep and observed higher dry matter and NDF intake, milk production and milk fat content for the soybean hulls diet,

Table 6 - Composition of fatty acids $(\mathrm{g} / 100 \mathrm{~g})$ of milk from Saanen goats fed soybean hulls replacing ground corn

\begin{tabular}{|c|c|c|c|c|c|c|c|}
\hline \multirow{3}{*}{ Fatty acids } & \multicolumn{5}{|c|}{ Diets $^{1}$} & \multirow[t]{3}{*}{$\mathrm{R}^{2}(\%)$} & \multirow[t]{3}{*}{$\mathrm{CV}(\%)$} \\
\hline & \multirow{2}{*}{$\begin{array}{l}\text { OSBH } \\
(n=3)\end{array}$} & \multirow{2}{*}{$\begin{array}{l}50 \text { SBH } \\
(\mathrm{n}=5)\end{array}$} & \multirow{2}{*}{$\begin{array}{c}100 \mathrm{SBH} \\
(\mathrm{n}=6)\end{array}$} & \multicolumn{2}{|c|}{$\mathrm{P}$ value ${ }^{2}$} & & \\
\hline & & & & $\mathrm{L}$ & Q & & \\
\hline & 1.12 & 0.96 & 1.01 & 0.525 & 0.323 & - & 18.0 \\
\hline $6: 0$ & 2.03 & 1.75 & 1.90 & 0.719 & 0.244 & - & 16.3 \\
\hline $8: 0$ & 2.84 & 2.55 & 2.66 & 0.785 & 0.570 & - & 23.1 \\
\hline $10: 0$ & 10.82 & 10.26 & 10.10 & 0.776 & 0.918 & - & 32.4 \\
\hline $12: 0$ & 5.10 & 5.02 & 4.36 & 0.580 & 0.811 & - & 43.6 \\
\hline $14: 0$ & 10.47 & 10.83 & 10.05 & 0.713 & 0.650 & - & 20.8 \\
\hline $14: 1 n-9$ & 0.16 & 0.14 & 0.20 & 0.076 & 0.101 & - & 23.2 \\
\hline $14: 1 n-7$ & 0.17 & 0.16 & 0.26 & 0.124 & 0.331 & - & 42.7 \\
\hline $14: 1 n-5$ & 0.11 & 0.12 & 0.09 & 0.297 & 0.235 & - & 27.7 \\
\hline $15: 0$ & 0.47 & 0.46 & 0.61 & 0.080 & 0.271 & - & 23.2 \\
\hline $15: 1 \mathrm{n}-10$ & 0.15 & 0.12 & 0.14 & 0.945 & 0.073 & - & 19.7 \\
\hline $16: 0$ & 23.83 & 25.87 & 25.23 & 0.375 & 0.183 & - & 6.6 \\
\hline $16: 1 \mathrm{n}-10$ & 0.13 & 0.07 & 0.12 & 0.965 & 0.052 & 1.00 & 36.6 \\
\hline $16: 1 n-9$ & 0.58 & 0.49 & 0.61 & 0.360 & 0.074 & - & 16.1 \\
\hline $16: 1 n-8$ & 0.66 & 0.71 & 0.68 & 0.922 & 0.758 & - & 31.2 \\
\hline $16: 1 n-7$ & 0.31 & 0.32 & 0.41 & 0.002 & 0.069 & 0.81 & 11.2 \\
\hline $16: 1 n-5$ & 0.10 & 0.13 & 0.09 & 0.757 & 0.344 & - & 60.2 \\
\hline $17: 0$ & 0.51 & 0.59 & 0.69 & 0.046 & 0.882 & 1.00 & 19.4 \\
\hline $17: 1 n-9$ & 0.42 & 0.49 & 0.49 & 0.663 & 0.767 & - & 42.9 \\
\hline $18: 0$ & 10.06 & 8.79 & 10.25 & 0.765 & 0.365 & - & 26.1 \\
\hline $18: 1 n-9$ & 26.13 & 26.98 & 26.31 & 1.000 & 0.836 & - & 23.6 \\
\hline $18: 2 n-6$ & 2.62 & 2.29 & 2.52 & 0.893 & 0.170 & - & 13.6 \\
\hline $18: 3 n-6$ & 0.15 & 0.10 & 0.15 & 0.123 & 0.001 & 1.00 & 12.7 \\
\hline $18: 3 n-3$ & 0.13 & 0.11 & 0.18 & 0.056 & 0.078 & 0.55 & 28.8 \\
\hline $18: 2$ (CLA) & 0.40 & 0.39 & 0.44 & 0.220 & 0.380 & - & 13.5 \\
\hline $20: 4 n-6$ & 0.24 & 0.22 & 0.25 & 0.757 & 0.478 & - & 22.2 \\
\hline $20: 5 n-3$ & 0.13 & 0.10 & 0.15 & 0.445 & 0.202 & - & 36.5 \\
\hline $22: 6 n-3$ & 0.07 & 0.09 & 0.09 & 0.222 & 0.752 & - & 29.7 \\
\hline
\end{tabular}


Table 7 - Grouped milk fatty acids (g/100g) from Saanen goats fed soybean hulls replacing ground corn

\begin{tabular}{|c|c|c|c|c|c|c|c|}
\hline \multirow{3}{*}{ Variables $^{2}$} & \multicolumn{5}{|c|}{ Diets $^{1}$} & \multirow[t]{3}{*}{$\mathrm{R}^{2}(\%)$} & \multirow[t]{3}{*}{$\mathrm{CV}(\%)$} \\
\hline & \multirow{2}{*}{$\begin{array}{l}0 \mathrm{SBH} \\
(\mathrm{n}=3)\end{array}$} & \multirow{2}{*}{$\begin{array}{l}50 \text { SBH } \\
(\mathrm{n}=5)\end{array}$} & \multirow{2}{*}{$\begin{array}{c}100 \mathrm{SBH} \\
(\mathrm{n}=6)\end{array}$} & \multicolumn{2}{|c|}{$\mathrm{P}$ value ${ }^{3}$} & & \\
\hline & & & & $\mathrm{L}$ & Q & & \\
\hline UFA & 32.60 & 33.03 & 33.18 & 0.908 & 0.922 & - & 20.2 \\
\hline MUFA & 28.86 & 29.73 & 29.40 & 0.935 & 0.875 & - & 22.1 \\
\hline PUFA & 3.73 & 3.30 & 3.78 & 0.509 & 0.037 & 1.00 & 9.3 \\
\hline LCFA & 40.85 & 40.15 & 41.51 & 0.885 & 0.845 & - & 22.1 \\
\hline$n-6$ & 2.77 & 2.39 & 2.67 & 0.957 & 0.122 & - & 13.1 \\
\hline$n-3$ & 0.33 & 0.30 & 0.42 & 0.008 & 0.018 & 0.58 & 13.6 \\
\hline PUFA/SFA & 0.06 & 0.05 & 0.06 & 0.701 & 0.242 & - & 17.0 \\
\hline$n-6 / n-3$ & 8.45 & 8.15 & 6.62 & 0.084 & 0.494 & - & 20.0 \\
\hline
\end{tabular}

but did not observe differences $(\mathrm{P}>0.05)$ for lactose and total solids content in milk.

The milk fatty acid profile (Table 6) presented changes for the different diets. The 16:1n-7 and linolenic (18:3n-3) fatty acids had positive linear effect with the addition of soybean hulls in the diet; however, for the linoleic acid (18:3n-6) there was quadratic effect, with lower concentration for the diet with $500 \mathrm{~g} / \mathrm{kg}$ of soybean hulls.

The differences observed for 18:3n-6 ( $\mathrm{Y}=0.1048+$ $\left.0.000082 \mathrm{X}+0.000018 \mathrm{X}^{2}\right)$ and $18: 3 \mathrm{n}-3(\mathrm{Y}=0.1364+0.000598 \mathrm{X})$ fatty acids in milk are due the variation in feed composition, since corn has a higher content of 18:3n- 6 and soybean hulls have a higher content of 18:3n-3. Nevertheless, although corn has a higher 18:1n-9 content, its effect was not observed because in the early lactation there is a body fat mobilization (negative energetic balance), which presented a high content of $18: 1 \mathrm{n}-9$ and can increase its concentration in milk fat.

The short chain fatty acids (SCFA) (Table 7) content $(16.0 \mathrm{~g} / 100 \mathrm{~g})$ were higher than those from the data observed by Maia et al. (2006), who used a total mixed dietbased on corn silage, oat, cottonseed meal, soybean meal and corn and observed SCFA content of $12.14 \mathrm{~g} / 100 \mathrm{~g}$. The higher production of acetic acid, which provides more synthesis of SCFA could explain the variation of the SCFA content.

The fatty acid influence on the development of blood cholesterol is measured by its variety of saturation groups, which have an effect on the levels of low-densitylipoprotein (LDL) and high-density-lipoprotein (HDL) in different ways. The saturated fatty acids tend to elevate even LDL as HDL concentration. However, this effect seems to be limited to fatty acids with 12 to 18 carbons of long chain, like the miristic (14:0) and palmitic (16:0), the most hypercholesterolemic fatty acids; the 10-carbon long chain fatty acids are inert for this system (Bessa, 1999; Dinoá, 2005).

The diet of $1000 \mathrm{~g} / \mathrm{kg}$ of soybean hulls provided a $27 \%$ increase of n-3 fatty acids (omega 3 ) when compared with the diet of $0 \mathrm{~g} / \mathrm{kg}$ of soybean hulls, and a $40 \%$ increase in comparison with the diet of $500 \mathrm{~g} / \mathrm{kg}$ of soybean hulls. Therefore the addition of soybean hulls in the diet it provided a positive linear effect $(\mathrm{Y}=0.3468+0.0011 \mathrm{X})$ of $\mathrm{n}-3$ fatty acids in the milk. This effect is beneficial to the consumer health, because n-3 fatty acids have been reported to prevent cardiovascular diseases and hypertension (Bessa, 1999).

\section{Conclusions}

Dry matter digestibility, production and physicochemical milk quality are not altered with soybean hulls in the diet. However, the 18:3n-3 and total n-3 fatty acids increase; therefore, soybean hulls can be used to replace ground corn in diets for Saanen goats in early lactation.

\section{References}

AGRICULTURAL AND FOOD RESEARCH COUNCIL - AFRC. Energy and protein requirements of ruminant. Wallingford: CAB International, 1993. 159p.

BAVA, L.; RAPETTI, L.; CROVETTO, G.M. et al. Effects of a nonforage diet on milk production, energy and nitrogen metabolism in dairy goats throughout lactation. Journal of Dairy Science, v.84, n.11, p.2450-2459, 2001.

BESSA, R.J.B. Revalorização nutricional das gorduras dos ruminantes. In: SYMPOSIOUM EUROPEO - ALIMENTACIÓN EM EL SIGLO, 21., 1999, Badajoz. Proceedings... Badajoz: Colegio Oficial de Veterinários de Badajoz, 1999. p.283-313. 
BOMFIM, M.A.D. Carboidratos solúveis em detergente neutro em dietas de cabras leiteiras. 2003. 119f. Tese (Doutorado em Zootecnia) - Universidade Federal de Viçosa, Viçosa, MG.

COCHRAN, R.C.; ADAMS, D.C.; WALLACE, J.D. et al. Predicting digestibility of different diets with internal markers: evaluation of four potential markers. Journal of Animal Science, v.63, n.5, p.1476-1483, 1986.

COOMER, J.C.; AMOS, H.E.; WILliAMS, C.C. et al. Response of early lactation cows to fat supplementation in diets with different nonstructural carbohydrate concentrations. Journal of Dairy Science, v.76, n.12, p.3747-3754, 1993.

DETMANN, E.; PAULINO, M.F.; ZERVOUDAKIS, J.T. et al. Cromo e indicadores internos na determinação do consumo de novilhos mestiços suplementados a pasto. Revista Brasileira de Zootecnia, v.30, n.5, p.1600-1609, 2001

DINOÁ, M.A. [2005]. Efeitos das gorduras no organismo. Available at: <http://www.saudeemmovimento.com.br/profissionais/ pesquisa/patologia/obsidade $>$ Accessed on: Oct. 30, 2005.

GOETSCH, A.L.; DETWEILER, G.; SAHLU, T. et al. Dairy goat performance with different dietary concentrate levels in late lactation. Small Ruminant Research, v.41, p.117-125, 2001.

GRAVERT, H.O. Dairy cattle production. New York: Elsevier Science, 1987. 234p.

HAENLEIN, G.F.W. [2001]. Goat milk somatic cell count situation in the United States. Available at: <http:// ag.udel.edu/ extention/information/goatmgt/gm-11.htm $>$ Accessed on: Mar. 24, 2005.

IPHARRAGUERRE, I.R.; IPHARRAGUERRE, R.R.; CLARK, J.H. Performance of lactating dairy cows fed varying amounts of soyhulls as a replacement for corn grain. Journal of Dairy Science. v.85, n.11, p.2905-2912, 2002.

IPHARRAGUERRE, I.R.; CLARK, J.H. et al. Soyhulls as an alternative feed for lactating dairy cows: A review. Journal of Dairy Science, v.86, n.4, p.1052-1073, 2003.

INTERNATIONAL ORGANIZATION FOR STANDARDIZATION ISO. Animal and vegetable fats and oils - Preparation of methyl esters of fatty acids. Geneve: Method 5509. 1978. p. $1-6$.

MAIA, F.J.; BRANCO, A.F.; MOURO, G.F. et al. Inclusão de fontes de óleo na dieta de cabras em lactação: produção, composição e perfil dos ácidos graxos do leite. Revista Brasileira de Zootecnia, v. 35, n. 4 , p. $1504-1513,2006$

MANSFIELD, H.R.; STERN, M.D. Effects of soybean hulls and lignosulfonate-treated soybean meal on ruminal fermentation in lactating dairy cows. Journal of Dairy Science, v.77, n.4, p.1070-1083, 1994.

MOURO, G.F.; BRANCO, A.F.; MACEDO, F.A.F. Substituição do milho pela farinha de mandioca de varredura em dietas de cabras em lactação: produção e composição do leite e digestibilidade dos nutrientes. Revista Brasileira de Zootecnia, v.31, n.1, p.475-483, 2002.

NATIONAL RESEARCH COUNCIL - NRC. Nutrient requirements of goats. Washington, D.C.: National Academy of Science, 1981. $91 \mathrm{p}$.
NATIONAL RESEARCH COUNCIL - NRC. Nutrient requirements of dairy cattle. 7. rev. ed. Washington, D.C.: National Academy of Sciences, 2001. 381p.

PEREIRA, J.R.A.; ROSSI, P. Manual prático de avaliação nutricional de alimentos. Piracicaba: FEALQ, 1995. 25p.

POORE, M.H.; ECK, T.P.; SWINGLE, R.S. et al. Total starch and relative starch avaliability of grains. In: BIENAL CONFERENCE ON RUMEN FUNCTION, 1989, Chicago. Abstracts... Chicago, 1989. v.20, p.35.

PRATA, L.F.; RIBEIRO, A.C.; REZENDE, K.T. et al. Composição, perfil nitrogenado e características do leite caprino (Saanen): Região Sudeste, Brasil. Ciência e Tecnologia de Alimentos v.18, n.4, p.428-432, 1998.

QUEIROGA, R.C.R.E.; COSTA, R.G. Qualidade do leite caprino. In: SIMPÓSIO INTERNACIONAL DE CONSERVAÇÃO DE RECURSOS GENÉTICOS, RAÇAS NATIVAS PARA O SEMIÁRIDO, 1., 2004. Recife. Anais... Recife: Universidade Federal Rural de Pernambuco, 2004. p.161-171.

ROBINSON, P.H.; McQUEEN, R.E. Influence of level of concentrate allocation and fermentability of forage fiber on chewing behavior and production of dairy cows. Journal of Dairy Science, v.80, n.4, p.681-691, 1997.

RUSSELL, J.B.; O’CONNOR, J.D.; FOX, D.J. A net carbohydrate and protein system for evaluation cattle diets. I. Ruminal fermentation. Journal Animal Science, v.70, n.11, p.3551-3561, 1992.

SARWAR, M.; FIRKINS, J.L.; EASTRIDGE, M.L. Effects of varying forage and concentrate carbohydrates on nutrient digestibilities and milk production by dairy cows. Journal of Dairy Science, v.75, n.6, p.1533-1542, 1992.

SILVA, D.J.; QUEIROZ, A.C. Análise de alimentos: métodos químicos e biológicos. 3.ed. Viçosa, MG: Universidade Federal de Viçosa, 2004. 235p

SNIFFEN, C.J.; O'CONNOR, J.D.; VAN SOEST, P.J. et al. A net carbohydrate and protein system for evaluating cattle diets: II. Carbohydrate and protein availability. Journal of Animal Science, v.70, n.10, p.3562-3577, 1992.

TRONCO, V.M. Manual de inspeção para a qualidade do leite. Santa Maria: Editora UFSM, 1997. p.88-110.

VAN SOEST, P.J.; ROBERTSON, J.B.; LEWIS, B.A. Symposium: carbohydrate methodology, metabolism, and nutritional implications in dairy cattle. Journal of Dairy Science, v.74, n. 10, p.3583-3597, 1991 .

VARGA, G.A; DANH, H.M.; ISHLER, V.A. The use of fiber concentrations for ration formulation. Journal of Dairy Science, v.81, n.11, p.3063-3074, 1998.

ZAMBOM, M.A.; ALCALDE, C.R.; SILVA, K.T. et al. Ingestão, digestibilidade das rações e produção de leite em cabras Saanen submetidas a diferentes relações de volumoso:concentrado. Revista Brasileira de Zootecnia, v.34, n.6, p.2505-2514, 2005a (supl.).

ZAMBOM, M.A.; ALCALDE, C.R.; SILVA, K.T. et al. Curva de lactação e qualidade do leite de cabras Saanen recebendo rações com diferentes relações de volumoso: concentrado. Revista Brasileira de Zootecnia, v.34, n.6, p.2515-2521, 2005b (supl.).

ZENOU, A.; MIRON, J. Milking performance of dairy ewes fed pellets containing soy hulls as starchy grain substitute. Small Ruminant Research, v.57, p.187-192, 2005. 